\title{
Engels as Sociologist
}

\author{
ALFRED G. MEYER \\ University of Michigan, Ann Arbor, MI, U.S.A.
}

\section{ABSTRACT}

The system of ideas developed by Engels and Marx belongs to the category of grand sociological theory in the manner of Hegel and Comte, Gumplowicz and Weber, but differs from them in essential elements, which are briefly summarized. Like other grand theories, it is rich in provocative ideas, and relative methodological flexibility can be orbserved in the attempts that Engels made to study discrete social institutions, such as the family and the military, or the sociology of ideas. But while Engels can be credited with a wealth of thoughtprovoking statements and questions in these and other areas, his work on them remained too fragmentary to have a major impact on the development of sociology in the Western world.

SOatology, aS IT IS understood today, originated in the grand theories of the eighteenth and nineteenth centuries; and among these the theory developed by Engels and Marx is one of the most important. As the cocreator of that grand theory which is usually called Marxism (his contribution to it is often under-rated.), Engels therefore must be recognized as one of the pioneers of modern sociology. One might argue, moreover, that a good deal of late nineteenth-century sociological theory-names such as Gumplowicz, Spencer, and Weber come to mind-developed in response to theories rightly or wrongly attributed to Engels and Marx. In the writings of these and other contributors to modern sociology, "Marxism" was often the theory to be refuted. What Marxists like to call "bourgeois sociology" directed much of its thrust against the system-menacing theories of Engels and Marx. That, in the process, they may have adopted many of the positions of their antagonists is easily overlooked.

In linking the theory developed by Marx and Engels with the grand theorists of "bourgeois sociology" I have some of the following traits of Marxism in mind. First, it seeks to comprehend any given society as a total system in which the structures and functions of all the component elements are related to each other and to the basic aim attributed to the whole. In this complex totality, the social structure, or, more specifically, the social division of labor, constitutes the basic point of reference, almost as if it were the independent variable that ultimately explains all other features-government, religious life, foreign policy, family and gender relations, education, art, and science. According to Engels, the social division of labor serves as this central coefficient to which all other social life is related because productive labor is, to him, the most essential activity for the maintenance of any social system. Throughout his writings Engels stressed the universal interconnectedness of all societal 
institutions and practices and came up with interesting examples of such linkages again and again. I will adduce some examples below. The link often is provided by structured inequalities, the most basic one being inequalites in property. But Engels stressed the need for inequalities in all social organizations. For any social action to take place, groups must organize to devise methods for discussion, agreement, decision-making, and management. Hierarchical organization was, for Engels, a universal given (17/478) ${ }^{1}$.

Engels repeatedly stressed his claim that his and Marx's theory was an objective search for regularities in the structure, functioning, and inter-relations of various social groups and institutions. In today's parlance, objectivity usually is defined by methodological criteria, including quantification, verifiability of hypotheses, and replicability of experiments. Implied in this emphasis on methodology is a suspicion of the tradition of grand theory. Engels, however, insisted that his method was superior to rigorous empiricism. This claim of methodological superiority is expressed in this characterization of his method as dialectical. What this meant to him might be summarized as follows: The dialectic is an ontology of process and change, motion being attributed to all reality. In human affairs, change is to be explained in part by the antagonism prevalent in all societies due to inequalities of power, status, wealth, and other social goods. Structured inequality is assumed to be the basic given in any social system and institutions.

Because every society is a structure of inequalities, all social systems are assumed to be antagonistic, i.e., conflict-ridden. Were it not for the various sub-systems, which function as system-maintenance devices, every society would disintegrate. Yet, says Engels, the more such devices are needed, the less effective they are likely to be $(21 / 165)$. What becomes apparent here is the emphasis which Engels, on the basis of the dialectic, gives to the limitations inherent in human action. He defines human beings as distinguished from other animals by thcir ability, through social action, to solve problems. Human beings are problem-solving animals. They solve the principal problem, that of securing the survival of the species in maximal comfort and security, by an activity called production. All social systems are seen as machineries to attain this aim, and, according to Engels, these machineries have become increasingly more efficient. Yet none so far has been perfect; on the contrary, every time human beings have solved some major problem they have thereby created new ones. Every social system, while an improvement over the preceding one, has contained inherent flaws that in the end turned out to be lethal. Hence, Engels considered it an objective law of history that every historical phenomenon would perish as a consequence of its own development $(20 / 161)$.

In one of his earliest works, the "Outline of a Critique of Political Economy," which can be regarded as one of the founding documents of Marxism, Engels applied this generalization to contemporary liberal society by arguing that the rules of free enterprise destroy the free-enterprise system. This simple assertion may be considered the core assertion of Marxism; for Marx- 
ism is not only an inversion of Hegelian philosophy but, more importantly, an inversion of liberal political economy (1/502 ff.).

All social institutions, Engels assumed, arise out of societal needs. Since human beings are assumed to be ingenious, all institutions arc assumed to begin by effectively responding to these needs, but all end up by defcating their initial purpose. Thus, free enterprise is an apt solution to the insoluble dilemmas faced by the precapitalist order, but its own rules of the game also spell its eventuall malfunctioning. What Engels suggests here is part of the theme of alienation which, in its broadest meaning, states that, recurrently, the creators of social institutions lose control over them and become helpless subjects of their own creations, a process which also spells the loss of many qualities - freedom, the dignity of creative work, cooperative relations with others, etc. - that make life worth living (20/253-258).

A related image pervading Engels's sociology is the pervasiveness of processes of institutionalization, as expressed in the dialectic of base and superstructure. The base that Engels has in mind is the sum-total of the productive forces, which he assumes to be developing continually. In every epoch, a system of societal institutions develops that is appropriate to the mode of production. But this superstructure, once formed, strives to perpetuate itself. Originating as a congeries of system-supporting devices, it gradually turns into a hard crust that threatens to strangulate the system. Like the exoskeleton of a crustacean, it must be broken and cast aside for the productive forces to go on developing.

Engels here, in effect, asserts the futility of conservatism. Social stability, he suggests, is a pipe dream; system-maintenance in the long run is an impossibility. Consequently, phenomena that mainstream sociology considers as deviations from societal norms, and hence system-threatening, are given positive evaluation, including criminality, evangelical religions, revolutionary movements, and revolutionary violence. The attitudes for which Engels shows greatest contempt are meekness, servility, and the acceptance of authority.

Engels repeatedly claimed that his interpretation of the dialectic was methodologically superior to inductive empiricism. His and Marx's theories, he asserted, were objective positive science. While he often made this claim in arrogant, dogmatic fashion, he also conceded that we cannot have finite knowledge of anything, partly because nothing is finite, change being an essential feature of reality. Hence all theories must remain open-ended, and whoever wishes to present a social system in its completeness must intuit or invent missing information (20/574). He even echoed Hegel in suggesting that the total configurations of a social system become apparent only after it has begun to disintegrate, so that all social knowledge is contingent, relative, and transitory (20/83). These reservations notwithstanding, he took the objective validity of his theories for granted.

If, to challenge this claim of scientific objectivity, it had been pointed out to him that, in fact, his writings were infused with passionate subjectivity, he would have acknowledged that cheerfully and eagerly. Several aspects of this 
subjectivity are worth touching upon briefly. I would call one of them faith, or religion; for the firm conviction that Engels expresses throughout his writings of the inevitable coming of a communist society without injustice or alienation, a social order worthy of all the noblest potential in human beings, is recognizably a secularized, anthropocentric, variant of the Calvinist faith in which he was reared. According to this conviction, the entire cosmos exists for the purpose of generating such ideal societies, in which matter would have attained selfconsciousness and sovereignty. The sociology of Engels, like that of many other grand theorists, is infused with teleology.

It need hardly be pointed out that everything he wrote is also informed by strong value judgments. His theory of modern society was motivated by an aesthetic and moral revulsion against the entire world of commerce and its consequences-the incqualitics of social stratification; poverty, squalor, criminality, and prostitution; the sexual bondage of the bourgeois marriage; liberal politics, including its injustices, its corruption, and its violence; ideology as the reign of stupidity; and the inauthenticity of an alienated life, with its pursuit of false needs and false values. Because he thought of himself as a cool, objective scientist and did not wish to appear as a sentimental phrasemaker, he often avoided expressing his revulsion directly, but the attitude comes through nonetheless. Still, the inverted Hegelianism, which stressed revolutionary action according to a script written by history, regardless of our attitudes and values, a script which consciousness could only recognize but not change-this inverted Hegelianism at times acted as an intellectual straightjacket.

Engels often threw caution to the wind and let his readers know very well what character and behavior traits he liked or disliked and what kind of social order he considered acceptable. While theory should be dispassionate in analyzing a moribund society, he wrote in his tract against Eugen Dühring, while moral indignation docs not constitute a scientific argument, yet "the wrath that makes the poet is entirely appropriate in depicting these ills or indenouncing those... who deny or prettify them." (20/139).

Undisguised value judgments of a moral and aesthetic kind inform not only his analysis of capitalism, but also his entire view of human history, which he expressly derived from that of Rousseau. Both Rousseau and Engels posited a transformation of pre-industrial, simple, closely-knit communities into complex urban societies populated by uprooted men and women alienated from everything noble and decent in their potential. Like Toennies and Weber, Engels was ambivalent about this trend. In some of his works he expressed nostalgia for the idyllic life he attributed to pre-industrial people (for an example, see 2/238-239), but just as often he would sneer at such an idealization of primitivism as a manifestation of petty-bourgeois sentimentalism. To be sure, primitive society as he described it afforded liberty, equality, dignity, sexual equality, and other goods to its members, while societies based on class divisions were marked by alienation, conflict, exploitation, subordination to authority, poverty side by side with wealth, and the transformation of human 
beings into objects. Yet all this, according to Engels, was progress: "The power of these nature-grown communities had to be broken and was broken. But it was broken through influences which to us from the very beginning appear as degradation, as a fall from the grace of the simple moral height of the old kinship-based society. It is the lowest impulses-common acquisitiveness, a brutal pleasure-seeking, filthy avarice, selfish theft of community property-which inaugurate the new, civilized class society;..." (21/97). Yet this is progess.

His contempt for pre-industrial ways of life is seen most clearly in his treatment of rural life. In his unfinished travelog of his hike from Paris to Geneva, in 1848, he referred to the peasants he met as "barbarians in the midst of civilization" and suggested that the deplorable limitations of village life can be overcome only to the extent that, through commerce, contact with the city is established (5/471,479;20/251-255). This contempt for the small, simple, selfcontained Rousseauian community, flourishing undisturbed by the high winds of world politics, comes out also in his scornful analysis of the Swiss democracy and his negative appraisal of South-West German Liberalism (4/391-398; $7 / 138,202$ ).

Engels was aware of the tension between his claim to be presenting objective science and the venting of his feelings of aesthetic and moral revulsion. The tension resulted from the dual purpose of his work: he sought to describe and analyse, but also to raise consciousness and promote revolution. In the final analysis, he would have argued that in dialectic thinking objective science and value judgments will support each other.

Let me point out in passing that, as a guide to political action, the theories advanced by Marx and Engels have shown themselves to be unsatisfactory because of analogous tensions between the emphasis on patterns of historic development from which it would be foolish to deviate, on the one hand, and the stress on human activity and indeed on freedom, on the other. As a guide to further sociological research, which is of more immediate interest here, the framework left by Engels has also remained ambiguous. The key terms of his theories were never defined adequately, their meaning either assumed to be self-evident or incapable of hard-and-fast definition, since in the dialectic all concepts ultimately dissolve.

When Marx was about to publish volume I of Das Kapital, a work on which he had labored for twenty years and for which, in a letter to a friend, he claimed to have sacrificed his health, his happiness, and his family, he explained the long gestation period of the work to Engels by stating that he never could have been satisfied with partial results: "I cannot get myself to send away anything before the total work is in front of me. Whatever shortcomings they may have, that is the advantage of my writings that they are an artistic whole..." To this he added that the dialectical structure of his writing imposed this need for completion on him. Seven months later he added the following selfappraisal: "You understand, my dear fellow, that in a work such as mine there must be many shortcomings in detail, but the composition, the 
coherence, is a triumph of German science,..." (Letters of Karl Marx to Sigfried Meyer, 30 April 1867; to Friedrich Engels, 31 July 1865, and 20 February 1866).

It is tempting to reverse this evalution not only as it applies to the oeuvre of Marx but also to that of Engels. To be sure, some basic propositions he advanced about the structure and functioning of liberal society have become commonplaces of contemporary social science. But his developmental scenario has been gainsaid by the course of modern history, while anthropological work of the current century has deeply challenged much of his historical sociology. Much of the grand theory Engels presented has degenerated into sectarian dogma of many contending orthodoxies, whose squabbles invite the scoffing of nonbelievers.

But an attentive reader of Engels's work will discover a wealth of perceptive sociological observations which, were they pursed systematically, would yield a large number of hypotheses worth testing. Engels was a keen observer of people and their relations. He read widely and voraciously in many languages, had traveled throughout Europe, and moved easily among people from many different classes. Ever since, at the age of 16, he had left his parental home, he had written down his observations. From early on these writings betrayed his quick and critical perception; they show him to have had an outstanding talent for sociology.

His own long-range ambition was to be a revolutionary leader and a scholar, two careers that in his mind complemented each other because his scholarship was supposed to raise the workers' consciousness. But, while a number of his scholarly projects fit in with this image, others seem rather extraneous to the purposes of a would-be revolutionary leader. His projects for a history of Ireland and a history of Germany might be considered relevant. He himself would also have included his major preoccupation with the philosophy of science; but his interest in Germanic linguistics surely had no relation to his career as a revolutionary.

Much of his work remained fragmentary because he was diverted from it by other tasks. Certain ideas that can be found in his correspondence or in unpublished drafts remained undeveloped, but certain themes recur so often that they can be grouped together into a formal contribution; and on at least one sociological theme-the sociology of the urban slum-he produced a booklength treatise. In this well-known book he relates the class structure and property system of Manchester to phenomena ranging from the city layout to slum culture, criminality, and gender relations among workers. In a pamphlet written almost thirty years later, he came back to the sociology of the slum and introduced such variables as landlord-tenant relations and the ecological disasters produced by large cities. (2/passim)

The theme that goes through his entire life's work is the sociological approach to history; or, perhaps, one should call it a socio-anthropological approach, bccause in some of his writings he paid especial attention not only to land tenure patterns and economic activities but also to kinship ties and to 
the relationship of these to political developments (19/425-494). Throughout his writings on revolutions, he emphasized that the outcome of revolutions does not so much depend on the competence or incompetence of the leadership but on the social conditions prevalent at the time. Revolutions, of course, interested him more than any other historic processes, and much of his work can be regarded as the comparative study of this process, with attention paid to examples from Greek and Roman history, the victory of Christianity, the Reformation, the French revolutions of the 18th en 19th centuries, and the mid-19th century upheavals on the European continent. In studying any society, he eagerly looked for symptoms of decay of the political order, political disasters, scandals, and corruption, and the resulting loss of legitimacy.

Ultimately, of course, whether studying revolutions or calmer political processes, Engels went back to class divisions, class interests, and class struggles as the basic explanation. While his theory posits a very simple basic division between the owners and non-owners of productive property, in the analysis of concrete situations he made much finer distinctions. For instance, in explaining European politics in the 1840s and 1850s, he discussed the political roles not only of landlords, bourgeois, and proletarians, but also of Junkers, bureaucrats, and the military, of the petty bourgeoise, the peasantry, and the Lumpenproletariat. At times he attempted to make finer differentiations even within the working class (e.g., 7/126-128) and to take account of the political role played by formations not fitting into the division of classes, such as nations and nationalities. Moreover, he had interesting though undeveloped observations about different styles of bourgeois rule-British, French, Swiss, and Prussian-scattered through his writings, indicating that he was conscious of differences in political style and political culture even within European capitalism. Little of this, however, went beyond occasional clever observations.

During his lifetime, the writings that earned him the highest praise among a wide range of readers were his comments on the wars waged between 1848 and 1871. What made him famous and earned him his nickname, "General", was the astounding accuracy with which, despite a few major miscalculations, he managed to predict the course of campaigns and the outcomes of battles, and all that on information available to any newspaper reader.

Engels had been interested in the study of warfare ever since the revolution of 1848 and his own participation in partisan warfare a year later. In time he acquired a large reference library on military subjects, became a self-taught specialist, and wrote about these matters extensively.

Taken together, these writings contain elements of the sociology of warfare and the military. In various articles he presented a comparative sociology of armies past and contemporary, explaining differences in organization and strategy on the basis of socio-economic and cultural variables $(14 / 5-48 ; 11 / 411$ 412, 423-424). For instance, his treatment of changes in infantry tactics is based on a persuasive combination of socio-economic, political, and technological factors that determined the changing functions of the foot soldier 
from the 14th to the 19th century (20/597-603). These explanations by no means rely only on class structures, although, naturally, he often did dwell on the relationship between class structure and the character of armies. An example would be an essay on the Prussian army (16/53 ff); another would be his treatise on the English army, where he provided a sociological sketch of the relationship between officers and men, relating the class background of both to their respective manners and mores, attitudes and formal relations. The gentlemen of the officer corps and the enlisted lumpenproletarians, he argued, are separated by a social gulf so unbridgeable that, for this very reason, they can establish a businesslike relationship and a reasonably decent tone of discourse (15/605-620).

The range of themes touched upon in his writings on military affairs is wide. There are biographical sketches of famous military leaders, written for the New American Cyclopedia, in which he embeds their personalities and leadership styles in their social, cultural, and political setting. There are studies that link troop morale and discipline to socio-cultural determinants (15/246-254; 270-274). Throughout his attempt to link warfare to social structure, Engels sought to reveal essential differences beneath seeming similarities. An instance would be his comparative treatment of the relationship between infantry and cavalry under Alexander the Great and the age of the Renaissance-this in a lengthy encyclopedia article cntitled "Infantry" written for the same New American Cyclopedia (14/351-352). Modern warfare, as pioneered by Napoleon I, he argued, presupposes a dense population; a civilized society; maximum mobility; literate, intelligent soldiers; and a bourgeois state (7/477-484). Indeed, the ultimate determinant of military potential is a country's state of development; modernization, he thought, would outweight such seeming advantages as superiority in numbers and fighting spirit. The army of the future, he thought, would be the entire nation mobilized and led by a professional officer cadre (15/534-540).

During the American Civil War, both Engels and Marx sided with the Union; but while Marx was convinced that the capitalist North could never be defeated by the army of a backward plantation society, Engels, observing the amateurism and incompetence of the Northern command, had his doubts, (15/486-495; 504-507), which caused Marx to chide him for stressing military aspects too much. The fact is that Engels was far from being a dogmatic determinist. For him the relationship between social structure and the military was reciprocal, and in his summary of their theory he expressly stated that wars may at certain times determine the social order (20/154-161). He further suggested that the study of military affairs was a good indicator of the strengths and weaknesses of any social system and that, therefore, one could expose the nature of a system by studying its warfare institutions $(14 / 340-367 ; 10 / 379)$.

His argument with Marx indicates the importance he attached to expertise and professioalism. Waging war, in his opinion, was a craft or skill to be acquired by hard professional schooling, hence amateurs and parade soldiers would be unsuccessful in battle, and so would be those who advanced into com- 
mand positions through patronage (15/384-388). In 1866 he compared the professionalism of the Austrian command with the clientelism reigning in William I's Prussian army, where promotion to high rank was determined by, or went to, the King's favorites, and on this basis he predicted an Austrian victory (16/169-173). His explanation of the defeat of Napoleon III was based on similar arguments $(17 / 78 ; 100)$. He seems to have thought that military skill tended to decline with the rise in military technology and with increasing affluence $(10 / 543 ; 17 / 132)$.

In addition to professional skill, he stressed the importance of correct organization, including a centralized command and the elimination of elite units $(10 / 598 ; 11 / 414-417 ; 16 / 170)$. If these opinions place him among the pioneers of modern organization theory at least potentially, it should be pointed out that he was also a Romantic humanist who was convinced that there were character traits essential to a military commander-steadfastness and courage, dash and daring, and a brilliant mind that could grasp an opportunity when it presented itself. Warfare to him was not only a craft but also an art; and here too he believed that with modernization the character traits conducive to this art tended to decline. Like Max Weber, he regretted the replacement of grace by rationality.

Toward the end of his life, he observed the growing intensity of nationalism, chauvinism, and militarism in Europe and predicted that the next war would be of devastating dimensions $(17 / 616 ; 21 / 252-256 ; 351 ; 22 / 45,48$, 396-399).

Another area in which Engels generated interesting ideas was the sociology of religion. Marx, in one famous phrase, had characterized religion as a painkilling drug and a fantasy solution to seemingly insoluble social problems. In a more sociological vein, Engels, who wrote about religious subjects from his teens to the last year of his life, interpreted religions as social protest movements. They arise among the poor and the oppressed, provide an organization framework for their underground activities, and give coherence to their hopes as well as to their hatred of the oppressors and their yearning for vengeance. Christianity, in its original form, was one of his favorite examples of such a protest movement. He declared it to have been "progressive" in its time and compared it to the initial phases of the socialist movement in many of its structural details-from the radicalism of its message and the class basis of its adherents to its proneness toward divisive sectarianism and the difficulty it must have had in collecting dues (19/297-305; 21/9-10; 22/447-473).

He interpreted the religious heresies since the Middle Ages as manifestations of middle- and lower-class rebellion (21/304) and compared Luther, Calvin, and other leaders of the Reformation to revolutionary leaders of the 18 th and 19th centuries, adding that, regrettably but predictably (by hindsight), Lutheranism had turned into an ideology of legitimation for monarchic absolutism (22/300). Anticipating Weber, he argued that Calvinist religious doctrine had facilitated the development of capitalism (18-591) and that, in general, Protestant attitudes had made it possible for Germany to recover from 
the ravages of the Thirty-Years' War. The Calvinist theory of predestination, he argued, was an eloquent reflection of the unpredictability of the market and hence was well suited to encourage bourgeois entrepreneurship. Moreover, the Calvinist church constitution was democratic and republican; hence, while Lutheranism became the ethos of subjects to absolute princes, Calvinism created a republic in the Netherlands and strong republican parties in England and Scotland (16/247;22/300-301). Altogether, he attributed to the Protestant ethic a liberating effect on enterprise, politics, philosophy, and other fields (18/594-595).

Another abiding interest of Engels was the comparative study of the family. This interest arose from the same motives as those for religion, since it was within his family that he had received his own strict Calvinist upbringing, and his emancipation from religious beliefs had also implied a break with his family. An unhappy courtship then became an additional motive for questioning the entire institution of marriage as it was then taken for granted.

In his first draft of the Manifesto of the Communist Party, he implied that by studying the family we can learn about the entire society because the family is a miniature analog of the total social system (4/377). Decades later, in The Origin of the Family, Private Property, and the State, he elaborated on this by suggesting linkages between the gender division of labor and the development of class differences. His views on middle-class marriage arc well known: Just as capitalism has turned human labor into a commodity, so it treats female sexuality and reproductive power as marketable merchandise, so that the bourgeois marriage turns into a form of life-long prostitution. Engels wrote about middle- and upper-class ladies with an attitude composed partly of compassion and partly of contempt-contempt for being no more than decorative drawing-room dolls, compassion because Victorian social mores and the double standard in sexual morality imprisoned them in this role. Incidentally, he was sensitive to differences between Catholic and Protestant cultures with respect to gender roles and family life.

Underneath his compassion and contempt for bourgeois women was a Romantic yearning for a society in which genuine love would be the only reason why any two people would want to live and sleep together, and in which such cohabitation would be a purely private affair without benefit of clergy or city hall. In the society of the future, he cheerfully predicted, all children would be born out of wedlock.

In his comments on gender relations among the working class, he suggested that such genuine love matches already prevailed to some extent, although in the urban slum the dissolution of the family worked as a hardship, not a blessing, if only because it led to the neglect of the children. Slum conditions produce people who are incapable of developing the ability to love. In that sense, they not only destroy conventional family life but also prevent a more desirable form of gender relations to develop (2/369-371). Moreover, while working class couples may be free from the constraints of bourgcois sex- 
ual morality - a freedom Engels may have over-estimated-he recognized that this freedom was no less burdensome to women than the confines of bourgeois marriage codes. He recognized the double or triple burden falling on proletarian women and suggested that in the culture of poverty the traditional gender roles tended to be reversed-a trend that he deplored (ibid.).

Let me turn from the influence of social environment on character to Engels' contribution to the sociology of knowledge and begin with his and Marx's views on the origins and functions of ideology. In accordance with their grand theory, the intellectual history of the human race could be understood only within the determining framework of the material conditions and social relations within which ideas were generated. Every social system predetermines the contents of the reigning ideas, while the state of technology may either limit or expand the range of phenomena that can come into view. These generalizations taken for granted, Engels suggested a variety of topics that could be examined within the broad field of the sociology of knowledge or ideas. One of them was the comparative study of political ideas. Key concepts of social philosophy-democracy, freedom, equality, civic virtue, and the like-are given different meanings and acquire different functions from one social system to another. Hence, political philosophers must be understood within the context of their own societies, and their ideas or even their vocabulary may not be readily applicable to the present. An example that Engels discussed at some length would be the history of the concept of "equality" from the Greeks to the nineteenth century (20/95-100; 579-582).

He took a slightly different approach in an attempt to explain differences in English, French, and German socialism by reference to the socio-political conditions in which each of them arose. While the grand theory assumes that the liberal republic is the appropriate form for bourgeois class rule, he discussed Bonapartism as a frequent variant and took into consideration the different political cultures, be they authoritarian or libertarian, centralized and bureaucratic or preserving traditions of local and provincial self-government.

Above I alluded to the effect on human personalities which he attributed to the culture of the slum. There are other examples he gave of the effect of certain political institutions on character. For instance, in a letter to Marx (24 Oct. 1869) he suggested that colonial rule dehumanizes both those being ruled and those who do the colonizing: "In the history of Ireland one can see what disaster it is for a nation to have subjugated another nation. All the English infamies have their origin in the Irish Pale." What English rule had done to the Irish themselves he had stated in an earlier letter to Marx (27 May 1856) and in a published essay (16/501-502): After centuries of oppression by the English, he wrote, the Irish are alienated from their own country, and they all, including their aristocrats, have been reduced to a Lumpennation.

Engels here manifested an interest in political attitudes. As an advocate of revolutionary change, he was, of course, concerned to recognize symptoms of political alienation and mobilization and to understand the factors promoting or undermining legitimacy. He also was interested in the reasons why a revolu- 
tionary leadership would resort to terror and answered this question by suggesting that terror is the reign of people who themselves are terrified (letter to Marx 9 September 1870). His concern with the factors promoting revolutionary consciousness went beyond the tactical problem of assessing the proper moment for concerted action. In fact, therc is no indication that he believed such fine-tuned monitoring of workers' opinions might be possible. Instead, his concern was with the effect of social systems on character. I have given several examples of pertinent statements he made on this, but should perhaps provide a more general summary: He was not content with pointing out what slum living does to the poor or how colonial rule spoils the character of the rulers. More generally, he thought that his work, from the late 1830s to 1895, made clear that his hatred of capitalism was based foremost on the shaping that liberal socio-political culture gave to the human character. In bricf, what he had in mind was the set of behavior traits and attitudes conventionally ascribed to the bourgeois: the work ethic, frugality, rational calculation, a readiness for bargaining and compromising, the pursuit of self-interest, and other familiar bourgeois virtues.

His appraisal of these virtues was ambivalent. As for rational calculation, he thought it impossible under capitalist conditions. The work ethic was an attitude that he seems to have expected to survive and blossom forth in the future communist society. For many other so-called bourgeois virtues he expressed respect, especially when he compared the sophistication, honesty, and flexibility of the English businessmen with the clumsy, petty, and dishonest practices he attributed to their German colleagues. But, in the final analysis, he expressed contempt for the political culture of liberalism: he considered it unheroic (22/301).

Moreover, he believed that modern development spelled the decline of the classical bourgeois virtues altogether, for he saw capitalism itself being transformed. His later writings contain germs of a theory of corporate capitalism. He noted the growth of cartels, trusts, and other forms of monopoly and oligopoly, the trend toward protectionism and other ways of obviating the laws of the market, financial control by banks and government interference, the managerial revolution, in which control by owners gives way to management by a salaried business bureaucracy, and the concomitant growth of the modern leviathan state $(20 / 261)$. He also noted the increasing frequency of scandals and corruption, and suggested that in modern capitalism it was becoming more and more difficult to reap profits honestly (19/6-7; $17 / 458-459 ; 22 / 358-364)$. Meanwhile, as the old bourgeois virtues were being corroded, he also thought that the English working class was losing its revolutionary elan: the proletariat was being bourgeoisified (21/197).

As a scholar-or would-be scholar-Engels projected a number of works he wished to write, his most favorite project being a philosophy of science, which obviously was meant to be a materialist inversion of Hegel's Phenomenology of Mind. Given his inclination to relegate intellectual activity to the superstructure, and indeed secing it as the part that was most remote from 
the socio-economic base, one might have expected him to treat the development of science as ideology and thus produce a sociology of science.

Indeed, he did point out that all theoretical models in natural science are products of different social systems, human thought itself having a social history. Scientific knowledge, he argued, develops in response to human needs, and they in turn are determined or defined by social systems (20/330331 and passim). When he compiled historic lists of key inventions, he obviously had in mind some eventual linking of human inventiveness and innovation with the society in which it arose. Moreover, he asked himself why the major scientific breakthrough which, in his opinion, ushered in the modern age, occurred around 1450 and not, say, around 300. In response, he identified a number of social givens that favored the intellectual development known as the Renaissance: a unified Western culture in which the learned freely communicated in a common scholarly language, the invention of printing, medieval craftsmanship and burgher enterprise, the expansion of the physical world through discoveries, the growth of universities, and the fall of Constantinople (20/462-463). Similarly, he attributed the development of science from Galileo to Newton to similar sociological determinants: the growth of cites with their burgher culture, peasant rebellions, the rise of royal absolutism, the Reformation, the rediscovery of Greek writings, and the great geographic discoveries (20/464 ff.). But, curiously, he did not go bcyond such commonplace observations, and his voluminous drafts on the subject suggest that he was not about to do so.

The explanation for this may be that, in the final analysis, he did not consider scientific innovation to be part of the ideological superstructure but, instead, regarded it as an essential element of the base. Socio-economic structure may be the framework determining the direction, the methods, and the limitations of scientific inquiry, but the dynamics of social change, in turn, are the results of improvements in the productive forces of society. Growth in the productive forces serves as the ultimate independent variable in Engels' grand theory; and it results from human ingenuity and inventiveness, i.e., from science.

His major work on science, therefore, would not have turned into a sociology of science. Instead, it was meant to be a treatise on scientific method: Engels deplored the modern insistence on empiricism and inductive reasoning. He thought they seriously limited our ability to theorize and to understand. It would have been a defense of dialectical reasoning (20/330-331 and passim).

It may be worth noting, in passing, that his wide acquaintance with the scientific work of this time, together with his Romantic awareness of the damage wrought by reckless capitalist exploitation of natural resources, made him sensitive to ecological issues: industrial blight in big cities; the need to recycle waste materials; the exhaustion of arable soil, to name a few. Here, too, he might have argued that a dialectical approach, recognizing the interdependence of all living matter and its environment, would have alerted scientists to such issues, and he criticized Darwin, whom otherwise he greatly admired, for failing to do so. 
I could adduce additional topics of interest to sociologists that Engels touched upon: the political sociology of underdevelopment; accasional remarks about the relationship between art and society; or, perhaps, wry observations about the social psychology of radical exile communities (18/528-529). But enough has been said to establish that, within the framework of his and Marx's grand theory, he touched upon a wide variety of relevant topics, and he did so with attention to complexities and cultural differences which suggests that his grand theory, while serving as a broad framework, did not confine or narrow him. Engels may have presented some of his theories in arrogant style, but he was far from being a dogmatist.

Not a single one of the sociological themes he touched, with the exception of the sociology of the working class slum, turned into a major work. One can explain this by arguing that his need to make a living to provide for himself and the Marx family prevented him from pursuing full-time studics. Once he had retired from business as a wealthy rentier, the demands of the socialist movement and loyalty to Marx and his intellectual heritage further interfered with his own scholarly projects: Volumes II and III of Das Kapital had to be put into publishable form, and the manuscripts that Marx had left for this work were in such a deplorable state that it took Engels more than a decade to complete this work.

One could also dismiss these excuses by arguing that they served Engels well by enabling him to hide behind them. Lacking these excuses, why would he not have converted his many suggestive hypotheses into major contributions? Many other social scientists have produced volumes of monographs on the basis of far fewer innovative ideas. There is nothing in his life or activitics suggesting that he might have been incapable of sustained scholarly work: He was immensely well read and endowed with a mind that absorbed new information quickly. He was meticulously systematic in his work habits and in organizing his time. Above all, he was able to make connections between seemingly unrelated phenomena.

One might argue that this broad sweep may have prevented him from concentrating on what Merton called middle-level generalizations; but, if nothing else, his work on the sociology of the military gainsays that argument. In the final analysis, it might be just as well to accept his excuses as valid.

Let me end with a brief observation about the attitude of this man to the academic professions. Engels had received an unfinished secondary education. When what he was learning at the Gymnasium in Elberfeld seemed to instill in him ambitions of becoming a writer or a professional intellectual-careers that his father considered unworthy of a solid bourgeois-his father made him leave school and go into a business apprenticeship instead. All of his life, Engels felt self-conscious about not having completed his secondary schooling and therefore not having studied at a university to obtain the coveted doctoral degree. Despite these handicaps, he did become a professional intellectual of sorts, a writer of scholarly books and articles, a selftaught polymath. He was proud of this, but particularly of the fact that this made him an outsider within the 
scholarly profession. Much of his work is, indeed, that of a selfconscious outsider, who in his work expresses irreverence toward conventional methods and interpretations, a scornful attitude toward the intellectual conservatism and narrow methodological rigor of academic scholarship.

Outsiders often are the ones to challenge established verities and to make innovative contributions. In the case of Engels this was demonstrated in a history of the Frankish dialect that he wrote in 1882. Fascinated by dialect differences from one village to the next in his home district, in this essay he sought to show that the boundary between Frankish and Saxon went straight through this very area. He had read all the relevant literature, including not only the older classics but also the academic writings of the most recent years issuing from the so-called Young-Germanistic school. But he went beyond this literature and was ahead of the professional Germanists of his time in identifying a special Frankish dialect and establishing the boundaries of the region in which it has survived. Frankish had not at that time been recognized as an independent dialect of German; today it is so recognized.

Engels later argued that the artificial and arbitrary boundaries between High German and Low German then acknowledged had not allowed the recognition that there might be an intermediary dialect. For him, it was an illustration of how the dialectical approach negates hard and fast boundaries established by meta-physical thinking (20/486). To me, the article proves the superiority of solid factual knowledge, when supported by a flash of insight and the outsider's chutzpah, over the methodological orthodoxies of academic scholarship. The Young-Germanists, whose works he had read, had developed a linguistic theory that concentrated on phonetics to the exclusion of other language aspects. Because he was self-taught, he knew more than the professors about the German language; or, more precisely, he was free to make use of knowledge that they also may have possessed but could not apply because it did not fit into their theories. In this case, therefore, Engels demonstrated the advantage of not having a Ph.D. and not being part of the academic establishment.

\section{NOTE}

All references in this article will be to Karl Marx and Friedrich Engels. Werke. Berlin, Dietz Verlag. I will cite volume and page numbers. 